\title{
KELIO SĄNARIO ENDOPROTEZO IŠNIRIMAS PO ENDOPROTEZAVIMO OPERACIJOS: KLINIKINIS ATVEJIS
}

\author{
Saulius Knystautas², Algimantas Čebatorius ${ }^{1,3}$, Deimantẻ Andriuškevičiūtė², \\ Daiva Mockevičiené ${ }^{3}$, Laurynas Kaušynis ${ }^{1}$ \\ ${ }^{1}$ Klaipèdos universitetiné ligonine, Traumatologijos departamento Traumatologijos skyrius, \\ ${ }^{2}$ Lietuvos sveikatos mokslu universiteto Medicinos fakultetas, \\ ${ }^{3}$ Klaipèdos universiteto Sveikatos mokslu fakultetas, Holistinès medicinos ir reabilitacijos katedra
}

Raktažodžiai: kelio sąnario endoprotezavimas, išnirimas, revizija.

\section{Santrauka}

Pristatome 70 metų pacientès, kuri kreipèsi ị KUL traumatologijos skyrių dèl 5 metus varginančio kairiojo kelio skausmo, klinikini atvejị. Apžiūros metu pastebèta, kad paciente vaikšto šlubuodama kairiaja koja, stebimas kairiojo blauzdikaulio panirimas, kelio sąnario valgusiné deformacija. Atlikus kairiojo kelio sąnario dviejų krypčių rentgenogramą, matomi ryškūs artroziniai kairiojo kelio sąnario pakitimai, blauzdikaulio kauliniai defektai, blauzdikaulio panirimas. Pacientę paruošus operaciniam gydymui, atlikta kairiojo kelio sąnario pirminè endoprotezavimo operacija specialiu Sigma TC-3 protezu. Atlikus kontrolines tiesinę ir šoninę kairiojo kelio rentgenogramas, pastebètas endoprotezo išnirimas (tibiofemoralinè dislokacija). Konsiliumo metu aptarus ir paruošus pacientę, operuota pakartotinai, panaudojant Sigma S-ROM stabilizuotą endoprotezą. Šis atvejis ypatingas tuo, jog kelio sąnario endoprotezo išnirimo komplikacija po visiško kelio sąnario endoprotezavimo operacijos yra itin reta komplikacija. Tinkamo dizaino endoprotezo parinkimas pacientui, esant pažengusiai kelio sąnario artrozei, vis dar išlieka daug diskusijų keliantis klausimas gydytojo ortopedo - traumatologo klinikineje praktikoje.

\section{Ivadas}

Osteoartritas - lètinè sąnarių liga, kuriai būdingas sąnarinès kremzlès irimas ir osteofitų susidarymas. Ši liga dažniausiai pažeidžia plaštakos, kelių, klubų bei stuburo (kaklo ir juosmens) sąnarius. Pagrindiniai osteoartrito simptomai yra pažeisto sąnario skausmas, sąstingis po poilsio bei sumažejusi sąnario judesio amplitudè. Osteoartritas yra labiausiai paplitusi artrito forma pasaulyje. Šios ligos sukeltas skausmas yra esminè judèjimo negalios priežastis [1]. Ilgą laiką osteoartritas buvo suvokiamas kaip degeneracinis sąnario kremzlès pažeidimas, tačiau šios ligos patogenezèje svarbūs chondrocitų ir sinoviocitų išskiriami uždegimo mediatoriai, kurie keičia kremzlès ir sinovijos ląstelių signalo perdavimo kelius bei genų ekspresiją. Pakitusi ląstelių tarpusavio sąveika kremzlès ir sinovijos audiniuose skatina uždegimo reakcijas, o ilgalaikis uždegimo mediatorių bei fermentų poveikis sukelia anatominį ir funkcinį sąnario pažeidimą [2]. Kelio sąnario osteoartritas reikalauja individualaus kompleksinio gydymo, pradedant neinvaziniais gydymo metodais, tačiau auksinis standartas gydyti pažengusį, konservatyviajam gydymui rezistentišką osteoartritą, yra kelio sąnario endoprotezavimo operacija [3]. Operacijos tikslas - sumažinti paciento skausmą, sąstingị ir atkurti visavertę judèjimo funkciją. Šios operacijos pasižymi maža komplikacijų rizika. Remiantis Lietuvos sąnarių endoprotezavimo registro 2011-2018 metų duomenimis, bendras kelio sąnario endoprotezų išlikimas siekia 96,69 procentus praejjus 96 mènesiams po pirminès operacijos. Kelio sąnario endoprotezo išnirimas - reta komplikacija, sudaranti tik 1,99 procento visų revizijų atvejų [4].

Atvejo analizès tikslas - išnagrinèti itin retą kelio sąnario endoprotezo išnirimo komplikacijos po visiško kelio sąnario endoprotezavimo operacijos atveji, aptarti šios komplikacijos diagnostikos ir gydymo metodiką, su rezultatais supažindinti ịvairių specialybių gydytojus.

\section{Klinikinis atvejis}

Pacientė 70 metų, atvykusi į Klaipėdos universitetinès ligoninès (KUL) traumatologijos skyrių, skundèsi kairiojo kelio skausmu. Varginantys skausmai trunka apie 5 metus. Apytiksliai vienerius metus kairiojo kelio sąnario būklè pablogèjusi, dèl skausmo sunkiai vaikšto. VLK paskirtas endoprotezas. Paciente stacionarizuota planine tvarka operaciniam gydymui. Iš anamnezès žinoma, jog pacientẻ serga sistemine raudonąja vilklige su širdies vožtuvų pažeidimu. 
Apžiūros metu pacientè šlubavo kairiaja koja, stebètas kairiojo blauzdikaulio panirimas, kelio sąnario valgusinè deformacija. Atlikus kairiojo kelio sąnario dviejų krypčiu rentgenogramą (1 ir 2 pav.), matomi ryškūs artroziniai kairiojo kelio sąnario pakitimai, blauzdikaulio kauliniai defektai, blauzdikaulio panirimas.

Atliktuose pirminiuose kraujo tyrimuose: leukocitozè, uremija, hiponatremija, glikemija, ADTL pailgèjęs (34,9 s), SPA ir INR tyrimai normos ribose. Reumatologo konsultacijos metu rekomenduota vartoti Medroli $4 \mathrm{mg} \mathrm{x} 1 \mathrm{p} / \mathrm{o}$, azatiopriną $50 \mathrm{mg}$ x 2 p/o, plakvenili $200 \mathrm{mg} \times 2$ p/o. Pacientę paruošus operaciniam gydymui, atlikta kairiojo kelio sąnario pirminė endoprotezavimo operacija specialiu Sigma TC-3 protezu. Pooperacinė eiga buvo sklandi, žaizda gijo pirminiu būdu. Atlikus kontrolines tiesinę ir šoninę kairiojo kelio rentgenogramas ( 3 ir 4 pav.), stebimas endoprotezo išnirimas (tibiofemoralinè dislokacija).

Konsiliumo metu aptarus ir paruošus pacientę, operuota pakartotinai, panaudojant Sigma S-ROM stabilizuotą endoprotezą. Pooperacinè eiga buvo sklandi, žaizda gijo pirminiu būdu. Atlikus kontrolines tiesinę ir šoninę kairiojo kelio sąnario rentgenogramas (5 ir 6 pav.): būkle po kairiojo kelio sąnario revizinio endoprotezavimo, komponentų ir



1 pav. Kairiojo kelio sąnario tiesinè rentgenograma
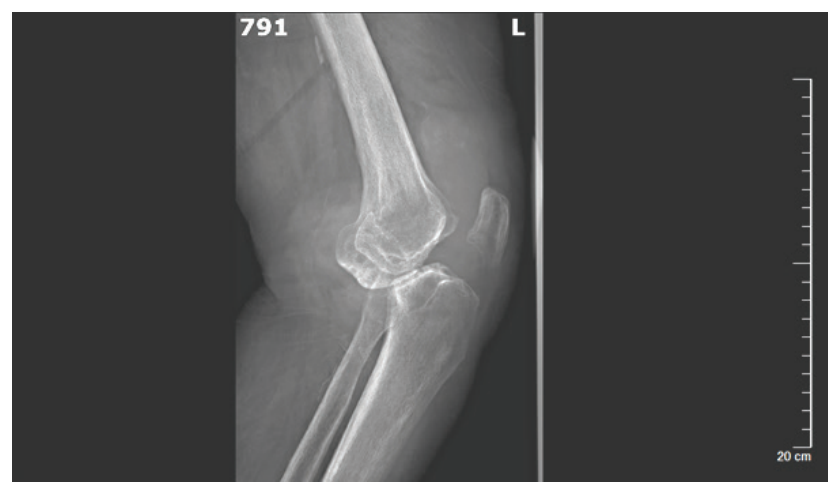

2 pav. Kairiojo kelio sąnario šoninė rentgenograma fragmentų padètis gera. Pooperaciniam gydymui skirti antibiotikai, infuzoterapija, analgetikai, antikoaguliantai, anemijos korekcijai sulašinti 4 vienetai eritrocitu masès. Pooperacinès apžiūros metu buvo stebima pagerejusi pacientès savijauta, skausmų sumažèjimas, kairiojo kelio sąnario judesiai didèjančios apimties, žaizda gijo pirminiu būdu. Pašalinus siūlus, paciente buvo siunčiama tęstiniam reabilitaciniam gydymui.

\section{Diskusija}

Šis atvejis ypatingas tuo, jog kelio sąnario endoprotezo išnirimo komplikacija po visiško kelio sąnario endoprotezavimo operacijos yra itin reta komplikacija. 2011-2017 metais Lietuvos sąnarių endoprotezavimo registro duomenų bazejje buvo užregistruotos 16048 pirminès kelio sąnario endoprotezavimo operacijos. Iki 2018-12-31 užregistruota 351 jų revizijų. Remiantis Lietuvos sąnarių endoprotezavimo registro duomenimis, 2011-2018 metais endoprotezo išnirimo komplikacija sudare tik 1,99 proc. visų kelio sąnario revizi-

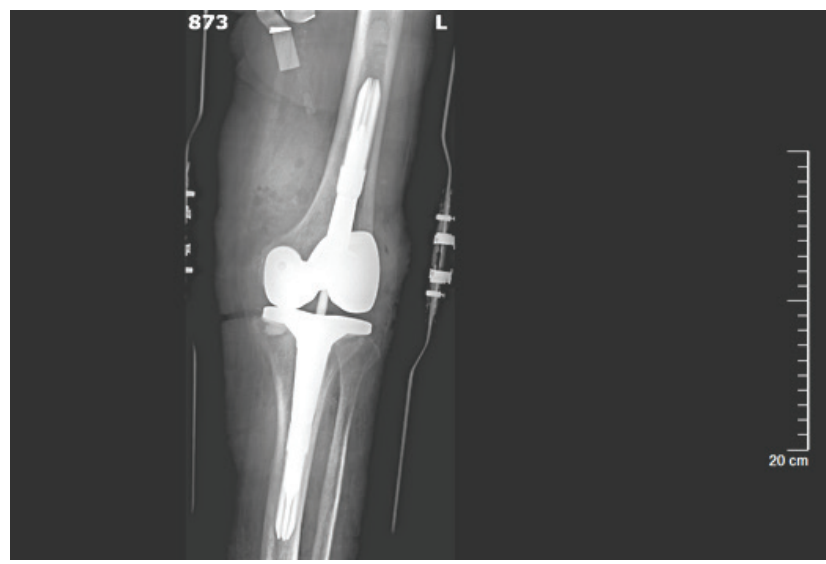

3 pav. Tiesinè kontrolinè rentgenograma po kairiojo kelio sąnario endoprotezavimo operacijos, panaudojant Sigma TC-3 endoprotezą

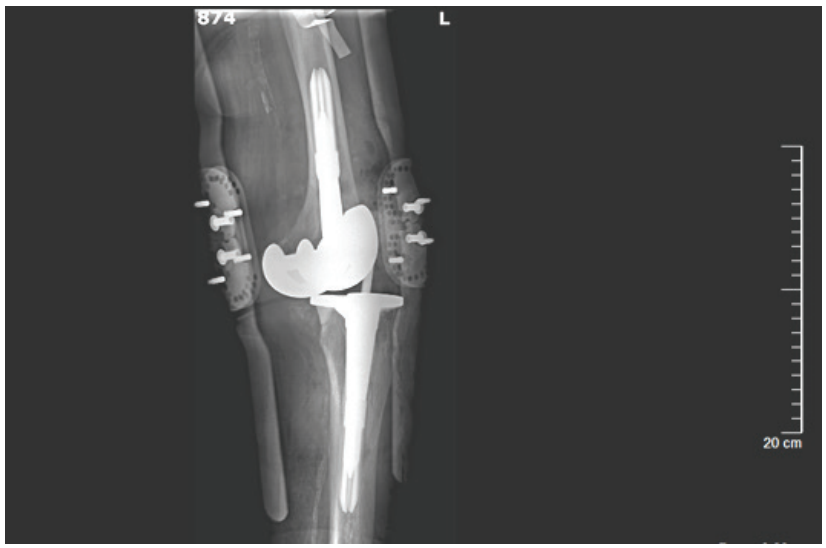

4 pav. Šoninė kontrolinė rentgenograma po kairiojo kelio sąnario endoprotezavimo operacijos, panaudojant Sigma TC-3 endoprotezą 
nių operacijų priežasčių [4]. Pagrindinè kelio sąnario endoprotezo išnirimo priežastis yra tibiofemoralinis nestabilumas. Tibiofemoralinis nestabilumas skirstomas $\mathfrak{i}$ tris pagrindines kategorijas: nestabilumas lenkiant, nestabilumas tiesiant bei hiperekstenzinis nestabilumas (lot. genu recurvatum).

Nestabilumas tiesiant. Remiantis ekstenzinio tarpo forma, nestabilumas tiesiant gali būti klasifikuojamas ị simetrinị ir asimetrinị (simetrinis nestabilumas, kai ekstenzinis tarpas yra stačiakampio, o asimetrinis - trapecijos formos). Simetrinis nestabilumas galimas dèl per didelès distalinio šlaunikaulio ar proksimalinio blauzdikaulio ekscizijos kelio endoprotezavimo operacijos metu. Dèl per didelès kaulo ekscizijos suformuojama per didelè ertmè, kurios nepavyksta užpildyti implantuojamais endoprotezo komponentais [5]. Proksimalinio blauzdikaulio per didelè ekscizija paveikia tiesimo ir lenkimo ertmes. Šiuo atveju problema išsprendžiama panaudojant storesnio diametro polietilenini intarpą [6]. Atlikus per didelę distalinio šlaunikaulio rezekciją, storesnio diametro polietileninio intarpo panaudojimas yra netinkamas pasirinkimas, nes pakeliama sąnario linija. Asimetrinis nestabilumas diagnozuojamas dažniau ir siejamas su anguliarine kelio sąnario deformacija, kurią sukelia persistuojantis ar jatrogeninis kolateralinių kelio raiščiu asimetriškumas. Kolateralinių raiščių asimetriškumą dažniausiai išprovokuoja nepakankamas medialinio ar lateralinio raiščio atpalaidavimas [7]. Šiam klinikiniam atvejui būdingas asimetrinis nestabilumas dėl kolateralinių raiščių pažeidimo ir degeneracinio kelio sąnario pažeidimo.

Rizikos veiksniai. Manoma, jog nutukimas, moteriškoji lytis ir neuromuskulinès ligos yra pagrindiniai kelio sąnario endoprotezo išnirimo rizikos veiksniai [8]. Nutukimas siejamas su padidèjusiu perioperaciniu nestabilumu dèl medialinio kolateralinio raiščio avulsijos [9]. Nèra konkretaus paaiškinimo, kodèl endoprotezo išnirimas po visiško kelio sąnario protezavimo operacijos dažniausiai pasitaiko mote-

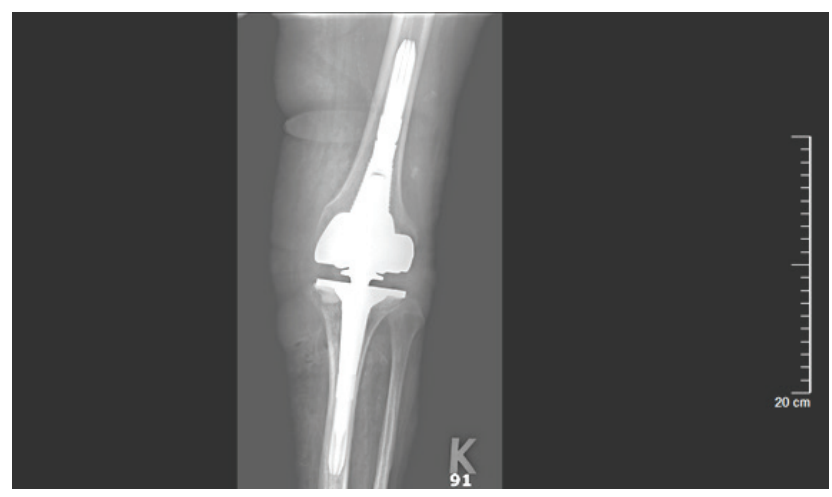

5 pav. Tiesinė kontrolinė rentgenograma po kairiojo kelio sąnario revizijos operacijos, panaudojant Sigma S-ROM stabilizuotą endoprotezą rims, tačiau manoma, jog tai gali būti siejama su padidejusiu raiščių ir sąnarių lankstumu, lyginant su vyrais. N. Heitz ir kt. (1999) nustate, jog priekinio kryžminio raiščio padidèjęs laisvumas susijęs su padidejjusia estrogeno ir progesterono koncentracija moters organizme [10]. Mūsų klinikinis atvejis patvirtino literatūroje minimus rizikos veiksnius: moteriškoji lytis ir I laipsnio nutukimas (KMI - 36,7).

Gydymas. Gydytojas, pasirinkęs atlikti visišką kelio sąnario endoprotezavimo operaciją, vadovavosi rekomendacijomis, nes pacientès atvejis atitiko 5 pagrindinius kriterijus. Pacientė jautė nuolatinị kelio sąnario skausmą apie 5 metus, kuris buvo rezistentiškas konservatyviajam gydymui, ịskaitant ir nesteroidinius vaistus nuo uždegimo; buvo atliktos diagnozę patvirtinančios tiesinè ir šoninè kairiojo kelio sąnario rentgenogramos, kuriose matomi ryškūs artroziniai kairiojo kelio sąnario pakitimai, blauzdikaulio kauliniai defektai bei blauzdikaulio panirimas. Paciente skundėsi pablogèjusia gyvenimo kokybe, nes jaučiamas skausmas sunkino galimybę atlikti visavertę judèjimo funkciją [11]. Daugiausiai diskusijų keliantis klausimas - tinkamo dizaino endoprotezo pasirinkimas. Šiuo atveju gydytojas, atsižvelgęs ị esamą kolateralinių kelio raiščių pažeidimą bei valgusinę deformaciją, pasirinko Sigma TC-3 protezo modeli. Sis protezas riboja valgusinès deformacijos sukeliamą kelio sąnario nestabilumą. Tokio dizaino protezų naudojimas pirminès visiškos kelio sąnario endoprotezavimo operacijos metu esant valgusinei deformacijai yra priimtinas sprendimas [12]. Remiantis atliktos metaanalizès duomenimis, valgusinę deformaciją ribojantys endoprotezai siejami su geresniais klinikiniais rezultatais, nedidejjant ryškių ankstyvujjų komplikacijų rizikai. Prieita prie išvados, jog valgusinę deformaciją ribojantys endoprotezai turetų ir toliau būti viena iš alternatyvų, atliekant pirminę kelio sąnario endoprotezavimo operaciją [13]. Remiantis Afton K. Limberg klinikinio tyrimo duomenimis, per 5 metus po kelio sąnario endoprotezavimo operacijos, naudojant

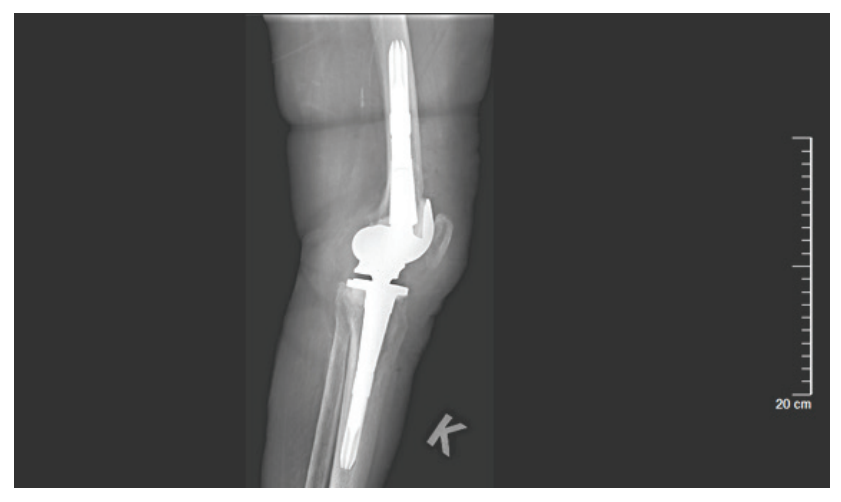

6 pav. Šoninė kontrolinė rentgenograma po kairiojo kelio sąnario revizijos operacijos, panaudojant Sigma S-ROM stabilizuotą endoprotezą 
valgusinę deformaciją ribojančius endoprotezus, pakartotinès revizinès operacijos prireikè tik 2 proc. pacientų dèl aseptinio endoprotezo laisvumo bei 4 proc. dèl endoprotezo komponentų nestabilumo [14]. Galima teigti, jog tokio tipo endoprotezu pasirinkimas yra tinkamas sprendimas iš paciento perspektyvos, nes pooperacinès komplikacijos yra retos.

\section{Išvados}

1. Aprašytas klinikinis atvejis parodo, jog tinkamo tipo endoprotezo pasirinkimas gydant pacientą su pažengusia kelio sąnario artroze, vis dar išlieka daug diskusijų keliantis klausimas gydytojo ortopedo traumatologo klinikineje praktikoje.

2. Valgusinę deformaciją ribojantys endoprotezai yra tinkamas pasirinkimas gydant pažengusią kelio sąnario artrozę su kolateralinių raiščiu nestabilumu, nes pooperacinių komplikacijų dažnis žemas.

3. Tikslios anamnezès surinkimas, fizinis ištyrimas, diagnozė ir tarpdalykinis specialistų bendravimas užtikrina geriausią paciento gydymo rezultatą, išvengiant gydymo komplikacijų, tokių, kaip kelio sąnario endoprotezo išnirimas po visiškos kelio sąnario endoprotezavimo operacijos.

\section{Literatūra}

1. Neogi T. The epidemiology and impact of pain in osteoarthritis. Osteoarthr Cartil 2013;21(9):1145-53. https://doi.org/10.1016/j.joca.2013.03.018

2. Chow YY, Chin KY. The Role of Inflammation in the Pathogenesis of Osteoarthritis. Mediators of Inflammation. Hindawi Limited 2020; 2020.

https://doi.org/10.1155/2020/8293921

3. Steinhaus ME, Christ AB, Cross MB. Total Knee Arthroplasty for Knee Osteoarthritis: Support for a Foregone Conclusion? HSS J 2017;13(2):207-10. https://doi.org/10.1007/s11420-017-9558-4

4. Lietuvos sąnarių endoprotezavimo registras. Sąnarių endoprotezuotojų asociacija. http://1ser.lt/

5. Cottino U, Rosso F, Pastrone A, Dettoni F, Rossi R, Bruzzone M. Painful knee arthroplasty: current practice. Current Reviews in Musculoskeletal Medicine 2015;8(4):398.

https://doi.org/10.1007/s12178-015-9296-5

6.PietschM,Hofmann S. Vondertibiofemoraleninstabilitätzurluxation in der knieendoprothetik. Orthopade 2007;36(10):917-27. https://doi.org/10.1007/s00132-007-1142-z

7. Peters CL, Jimenez C, Erickson J, Anderson MB, Pelt CE. Lessons learned from selective soft-tissue release for gap balancing in primary total knee arthroplasty: an analysis of 1216 consecutive total knee arthroplasties: AAOS exhibit selection. Journal of Bone and Joint Surgery 2013;95(20). https://doi.org/10.2106/JBJS.L.01686

8. Jethanandani RG, Maloney WJ, Huddleston JI, Goodman SB, Amanatullah DF. Tibiofemoral Dislocation After Total Knee Arthroplasty. The Journal of Arthroplasty 2016;31(10):2282-5. https://doi.org/10.1016/j.arth.2016.03.010

9. Winiarsky R, Earth P, Lotke P. Total knee arthroplasty in morbidly obese patients. Journal of Bone and Joint Surgery 1998;80(12):1770-4.

https://doi.org/10.2106/00004623-199812000-00006

10. Heitz NA, Eisenman PA, Beck CL, Walker JA. Hormonal Changes Throughout the Menstrual Cycle and Increased Anterior Cruciate Ligament Laxity in Females. Journal of Athletic Training 1999;34(2):144.

11. Schmitt J, Lange T, Günther KP, Kopkow C, Rataj E, Apfelbacher $\mathrm{C}$, et al. Indikationskriterien für den endoprothetischen Gelenkersatz bei Gonarthrose - eine multiperspektivische Konsensstudie. Z Orthop Unfall 2017;155(5):539-48.

https://doi.org/10.1055/s-0043-115120

12. Adravanti P, Vasta S. Varus-valgus constrained implants in total knee arthroplasty: indications and technique. Acta Biomedica Atenei Parmensis 2017;88(Suppl 2):112-117.

13. Avino RJ, King CA, Landy DC, Martell JM. Varus-Valgus Constraint in Primary Total Knee Arthroplasty: A ShortTerm Solution but Will It Last? The Journal of Arthroplasty 2020;35(3):741-746.e2.

https://doi.org/10.1016/j.arth.2019.09.048

14. Limberg AK, Tibbo ME, Pagnano MW, Perry KI, Hanssen $\mathrm{AD}$, Abdel MP. Varus-valgus constraint in 416 revision total knee arthroplasties with cemented stems provides a reliable reconstruction with a low subsequent revision rate at early to mid-term review. Bone Joint J 2020;102 B(4):458-62. 0719.R2. https://doi.org/10.1302/0301-620X.102B4.BJJ-2019-0719.R2

\section{CASE REPORT: ENDOPROSTHESIS DISLOCATION AFTER TOTAL KNEE REPLACEMENT \\ S. Knystautas, A. Čebatorius, D. Andriuškevičiūtè, D. Mockevičienė, L. Kaušynis}

Keywords: total knee arthroplasty, dislocation, revision.

Summary

We present 70 years old female patient who complains with frustrating pain of left knee joint. During clinical evaluation we noticed that patient has abnormal gait, tibiofemoral dislocation and valgus deformation of left knee. Futhermore, after X-ray evaluation of the left knee we noticed left knee advanced arthrosis with tibial bone spurs and tibiofemoral dislocation. Patient was indicated for total knee arthroplasty. Varus - valgus constraint Sigma TC - 3 endoprosthesis was obtained for left knee replacement. During postoperative X- ray evaluation we noticed tibiofemoral dislocation of endoprosthesis. Revision total knee replacement operation was indicated for patient because of postoperative complication. Sigma S-ROM endoprosthesis was obtained for the total knee replacement revision. Tibiofemoral dislocation after total knee replacement is rare postoperative complication. Decision of what kind of specific design of endoprosthesis to choose for total knee replacement for a patient with advanced knee arthrosis still is quite complicated and difficult in clinical practice of orthopaedic surgeon.

Correspondence to: a.cebatorius@gmail.com

Gauta 2022-01-05 